\title{
Utilization Activated Carbon from Bagasse in Processed of Laundry Waste
}

\author{
Dwi Putri Handayani, Nining Fitriana, Rusmini* \\ Department of Chemistry \\ Faculty of Mathematics and Natural Sciences \\ Universitas Negeri Surabaya \\ Surabaya Indonesia \\ rusmini@unesa.ac.id
}

\begin{abstract}
Research was carried out on the use of activated carbon from bagasse for processing laundry waste. The method used is the adsorption method with a variation of the length of contact between activated carbon and laundry waste. Laundry waste parameters analyzed included MBAS, phosphate, COD, BOD, TSS and $\mathrm{pH}$. The ability of adsorption of laundry waste in the 120 minutes was reduced the concentration of MBAS up to $80.14 \%$, phosphate up to $82.99 \%$, COD up to $79.34 \%$, BOD up to $77.28 \%$, TSS up to $77.09 \%$ and $\mathrm{pH} 7.05$.
\end{abstract}

Keywords- Bagasse, Activated Carbon, Laundry Waste, Adsorption.

\section{INTRODUCTION}

Laundry business is one type of home-based business that is currently developing throughout the city and rural areas. Laundry business in addition to providing positive benefits, also produces negative impacts, namely environmental pollution. The resulting environmental pollution comes from the rest of the laundry process that uses detergent. Detergents are generally composed of three main components consisting of surfactants (as a base for detergents), builders (phosphate compounds) and additives (bleach, deodorizers). Sodium tripolyphosphate (STTP) which is one of the ingredients in detergents which functions as a builder which is the second important element after surfactant, because of its ability to remove hardness minerals in water so that detergents can work optimally [1]. East Java Governor Regulation Number 72 of 2013 includes parameters of MBAS, Phosphate, COD, BOD, TSS, and $\mathrm{pH}$ [2]. Based on these parameters it can be an indicator to find out that laundry wastewater is still within the maximum allowed for each parameter.

In a laundry in Caruban East Java, the measurement of MBAS levels was $29,492 \mathrm{mg} / \mathrm{L}$, Phosphate was $23.55 \mathrm{mg} / \mathrm{L}$, COD was $1183.67 \mathrm{mg} / \mathrm{L}$, BOD was $370,25 \mathrm{mg} / \mathrm{L}$, TSS was $400 \mathrm{mg} / \mathrm{L}$ and $\mathrm{pH}$ 7.75. All conditions are above the maximum limit permitted according to the Governor of East Java Regulation so that processing is required before being discharged into the environment. Laundry wastewater treatment that can be done is adsorption. Adsorption is an event of absorption of a substance on a solid surface. The adsorption phenomenon occurs due to the pulling force between the adsorbate molecules and the active sites on the surface of the adsorbent [3].

Adsorption is a more effective method for tackling liquid waste pollution, because in addition to being easy to do also has high effectiveness. Adsorption using activated carbon is one of the potential ways to overcome laundry liquid waste. The basic materials of activated carbon are organic materials with high carbon content and are activated using $5 \mathrm{M} \mathrm{HCl}$.

Sugarcane bagasse is a residue from the process of grinding sugar cane after the squeeze process or the release is issued [4]. The supply of bagasse in Indonesia is quite abundant in line with the number of sugar cane sellers on the side of the road. Sugar cane produced in each sugar cane ice seller is burned, dumped in a trash or in an empty land [5]. Various utilization efforts have been made to minimize bagasse, but this effort has not been able to overcome the problem of bagasse. One of the basic considerations for making activated carbon is bagasse containing high levels of lignocellulose [6].

In ecotoxicology, a large number of tests find that LAS can cause acute and chronic toxicity to aquatic organisms. LAS with a concentration of 20$30 \%$ solution can cause tissue damage in mice after skin contact for more than 15 days. At a concentration of $25 \mathrm{mg} / \mathrm{L} \mathrm{LAS}$, the fish reacts with a pattern of increasing activity, inactivity and immobility, and if not removed from the system will cause death. Minimal effects related to biochemical changes and histopalogy in the liver have been $\iota$ laundry in Carul reported in subchronic toxicity tests for mice given a concentration of LAS $120 \mathrm{mg} / \mathrm{kg}$ body weight per day in food or drinking water [7].

This MBAS method is used to determine the concentration of surfactants in solution because the concentration of MBAS is proportional to the concentration of surfactants. The principle of phosphate testing is in an acidic atmosphere, 
ammonium molybdate and potassium antimonyl tartrate react with orthophosphate to form phosphomolybdic acid compounds and then reduced by ascorbic acid to become a molybdenous blue complex. COD is the amount of oxygen needed to remodel organic matter into carbon dioxide, water and ammonia. The BOD value of an aquatic is influenced by the amount of organic matter and pollutants in these waters [8]. Total Suspended Solid (TSS) is suspended solids that are not dissolved and cannot settle directly, consisting of particles of smaller size and weight than sediment [9]. The $\mathrm{pH}$ value is a parameter that is used to measure the degree of acidity or concentration of $\mathrm{H}^{+}$values in water.

This studied seeks to provide an alternative use of bagasse from sugar cane sellers to activated carbon which can then be used to reduce the concentration of MBAS, phosphate, COD, BOD, TSS and $\mathrm{pH}$ in laundry waste.

\section{RESEARCH METHOD}

\section{A. Equipments}

The tools used in this research are erlenmeyer, magnetic stirrer, analytical balance of OHAUS Pioneer TM, oven, $50 \mathrm{ml}$ volumetric flask, drop pipette, $100 \mathrm{ml}$ beaker, known volume of winkler bottle, burette, aerator, BOD inclusator, universal indicator and $\mathrm{pH}$ meter. The instrument used in this study was the UV-Vis Shimadzu UV-165 OPC spectrophotometer.

\section{B. Materials}

The materials used in this study are activated carbonfrom bagasse, laundry waste, Aquades, $\mathrm{H}_{2} \mathrm{SO}_{4}$ , potassium antimonyl tartrate, ammonium molybdate, ascorbic acid, potassium anhydrous phosphate anhydrous, $\mathrm{NaHPO}_{4} \cdot 2 \mathrm{H}_{2} \mathrm{O}$, $\mathrm{Na}_{2} \mathrm{CO}_{3}$ solution, starch / starch indicator solution, sodium thiosulfate solution $0.025 \mathrm{~N}, \mathrm{HgSO}_{4}$, potassium dichromate, powder or Crystal $\mathrm{Ag}_{2} \mathrm{SO}_{4}$, Potassium Hydrogen standard solution, phosphate buffer solution, magnesium sulfate solution, calcium chloride solution, ferric chloride solution, diluent solution, glucose-acid glutamate solution, manganese solution sulfate, azide iodide solution, $\mathrm{H}_{2} \mathrm{SO}_{4} 1 \mathrm{~N}$ solution, $1 \mathrm{~N} \mathrm{NaOH}$ solution, $\mathrm{pH} 4$ buffer and $\mathrm{pH}$ buffer

\section{Procedure}

The adsorption process is carried out by inserting 0.2 grams of activated carbon in $100 \mathrm{ml}$ of laundry waste then stirring with a magnetic stirrer for 30, 60, 90, 120 and 150 minutes. The method used for MBAS testing is SNI 06-6989.51-2005, Phosphate is Standard Methods 20th edition 1998, COD is SNI
6989.2-2009, BOD is SNI 6989.72: 2009, TSS is SNI 06-6989.3-2004, pH is SNI 06-69 6989.11-2004.

\section{RESULTS AND DISCUSSION}

A. Phosphate Test according to Standard Methods $20^{\text {th }}$ edition 1998

The principle of phosphate testing is in an acidic atmosphere, ammonium molybdate and potassium antimonyl tartrate react with orthophosphate to form phosphomolybdic acid compounds and then reduced by ascorbic acid to become a molybdenous blue complex. The reaction of acid formation fosfomolibdat at as in equation 1 :

$\left(\mathrm{NH}_{4}\right)_{6} \mathrm{Mo}_{7} \mathrm{O}_{24}+4 \mathrm{H}_{2} \mathrm{O} \rightarrow 6 \mathrm{NH}_{4}^{+}+7 \mathrm{MoO}_{4}{ }^{2-}+8 \mathrm{H}^{+} \ldots . .(1)$

The reaction step for blue phosphomolybdenum formation is as in equation 2 dan 3 :

$$
\begin{aligned}
& \mathrm{H}_{2} \mathrm{PO}_{4}^{-}+12 \mathrm{MoO}_{4}{ }^{2-}+25 \mathrm{H}^{+} \rightarrow \mathrm{H}_{3}\left[\mathrm{P}_{2}\left(\mathrm{Mo}_{3} \mathrm{O}_{10}\right)_{4}\right]+ \\
& 12 \mathrm{H}_{2} \mathrm{O}
\end{aligned}
$$

Askorbat acid

$$
\begin{gathered}
\mathrm{H}_{3}\left[\mathrm{P}\left(\mathrm{Mo}_{3} \mathrm{O}_{10}\right)_{4}\right]+4 \mathrm{H}^{+} \rightarrow \mathrm{H}_{7}\left[\mathrm{P}\left(\mathrm{Mo}_{3} \mathrm{O}_{10}\right)_{4}\right] \\
\text { Reduction }
\end{gathered}
$$

In Table 1 shows the average concentration of phosphate absorbed in the time variation, from the table it can be seen that the phosphate concentration decreases with increasing contact time. Based on Table 1, a graph is made by connecting the time as the $\mathrm{X}$ axis to the amount of phosphate concentration absorbed ( $\mathrm{mg} / \mathrm{L})$ as the $\mathrm{Y}$ axis. The graph results can be seen in Figure 1.

Figure 1 shows that at the contact time of 120 minutes, the percentage of phosphate concentration absorbed experienced the largest decrease of $82.99 \%$, whereas at the contact time of 30 minutes the percentage of phosphate concentration was the smallest at $69 \%$, but at contact time of more than 120 minutes the percentage of phosphate concentration

\begin{tabular}{|c|c|c|c|c|c|}
\hline \multirow[t]{3}{*}{ No } & \multirow{3}{*}{$\begin{array}{c}\text { Contact } \\
\text { Time } \\
\text { (minutes) }\end{array}$} & \multicolumn{3}{|c|}{$\begin{array}{c}\text { Phosphate Concentration } \\
(\mathrm{mg} / \mathrm{L})\end{array}$} & \multirow{3}{*}{$\begin{array}{l}\text { Percentage of } \\
\text { phosphate } \\
\text { concentration } \\
\text { absorbed }(\%)\end{array}$} \\
\hline & & \multirow[t]{2}{*}{ Early } & \multicolumn{2}{|c|}{ Average } & \\
\hline & & & End & Absorbed & \\
\hline 1 & 30 & \multirow{5}{*}{23.55} & 7.30 & 16.24 & 69.00 \\
\hline 2 & 60 & & 6.65 & 16.89 & 71.75 \\
\hline 3 & 90 & & 4.24 & 19.30 & 81.99 \\
\hline 4 & 120 & & 4.00 & 19.54 & 82.99 \\
\hline 5 & 150 & & 5.06 & 18.48 & 78.49 \\
\hline
\end{tabular}
absorbed has decreased.

Table 1. Average Absorbed Phosphate Concentration in Contact Time Variations 


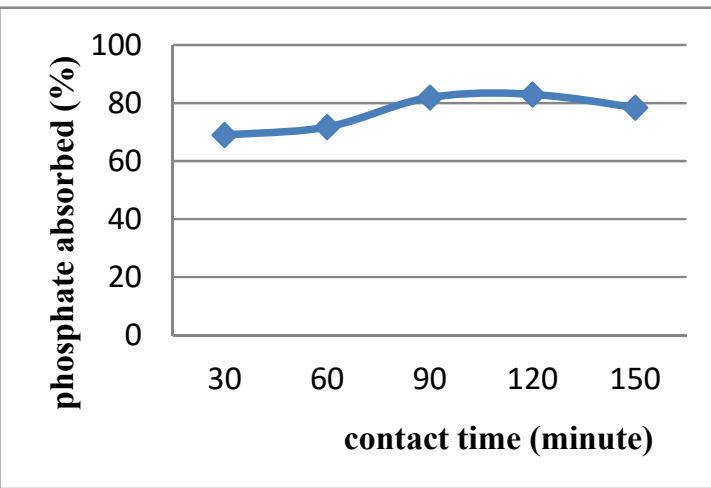

Figure 1. Graph of Phosphate Absorption in Time Variations

Activated carbon containing $\mathrm{H}^{+}$ions has a positively charged surface of the adsorbent particles, so that it can bind to negatively charged phosphate ions. Before the adsorption process, this $\mathrm{H}^{+}$ion on the surface binds to other anions. Negatively charged phosphate $\left(\mathrm{PO}_{4}^{-}\right)$allows bonding with positively charged adsorbents $\left(\mathrm{H}^{+}\right.$ions). In this adsorption process, phosphate anions will replace other anions that bind to the $\mathrm{H}^{+}$ion [10]. This is because the excessive contact time causes activated carbon to saturate and cause phosphate to escape the activated carbon pores (desorption occurs).

B. Methylene Blue Anionic Surfactant Test (MBAS) according to SNI 06-6989.51-2004

The MBAS method is useful for determining the content of anionic surfactants from wastewater. The core of the MBAS method are 3 sequentially, namely: Methylene blue extraction with anionic surfactant from the medium of water solution into chloroform $\left(\mathrm{CHCl}_{3}\right)$, then followed by the separation between the water and organic phases and the measurement of blue in $\mathrm{CHCl}_{3}$ using spectrophotometry at 652 wavelengths. $\mathrm{nm}$ [11].

The following is a description of the reaction (ion association) that occurs between methylene blue and surfactant:

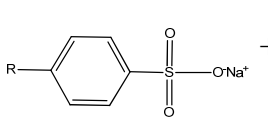

Anionic surfactant<smiles></smiles>

$+\quad \mathrm{NaCl}$
Figure 2 . The reaction between methylene blue and surfactant
$\mathrm{N}^{+}$ion can be seen from methylene blue interacting attack and bind with $\mathrm{O}^{-}$ions of the surfactant by electrostatic forces to form neutral species that can be extracted into an organic solvent. Whereas $\mathrm{Cl}^{-}$ions of methylene blue bind to $\mathrm{Na}+$ ions from surfactants and remain in the water phase. Anionic phosphatases react with methylene blue to form new ionic pairs dissolved in organic solvents, the intensity of the blue color formed is measured by spectrophotometer with a wavelength of $652 \mathrm{~nm}$. The measured uptake is equivalent to the level of anionic surfactants.

In Table 2 shows the average concentration of MBAS absorbed in the time variation, from the table it can be seen that the concentration of MBAS has decreased with increasing contact time.

Table 2. Average Absorbed MBAS Concentration in contact Time Variations

\begin{tabular}{|c|c|c|c|c|c|}
\hline \multirow[t]{3}{*}{ No } & \multirow{3}{*}{$\begin{array}{c}\text { Contact } \\
\text { Time } \\
\text { (minutes) }\end{array}$} & \multicolumn{3}{|c|}{ MBAS Concentration (mg / L) } & \multirow{3}{*}{$\begin{array}{c}\text { Percentage o } \\
\text { MBAS } \\
\text { concentration } \\
\text { absorbed }(\%)\end{array}$} \\
\hline & & \multirow[t]{2}{*}{ Early } & \multicolumn{2}{|c|}{ Average } & \\
\hline & & & End & Absorbed & \\
\hline 1 & 30 & \multirow{5}{*}{29.49} & 6.30 & 23.19 & 78.63 \\
\hline 2 & 60 & & 6.11 & 23.37 & 79.26 \\
\hline 3 & 90 & & 5.96 & 23.52 & 79.77 \\
\hline 4 & 120 & & 5.85 & 23.63 & 80.14 \\
\hline 5 & 150 & & 6.05 & 23.43 & 79.47 \\
\hline
\end{tabular}

Based on Table 2, a graph is made by relating the time as the $\mathrm{X}$ axis to the amount of MBAS concentration absorbed ( $\mathrm{mg} / \mathrm{L}$ ) as the $\mathrm{Y}$ axis. The results can be seen in Figure 3.

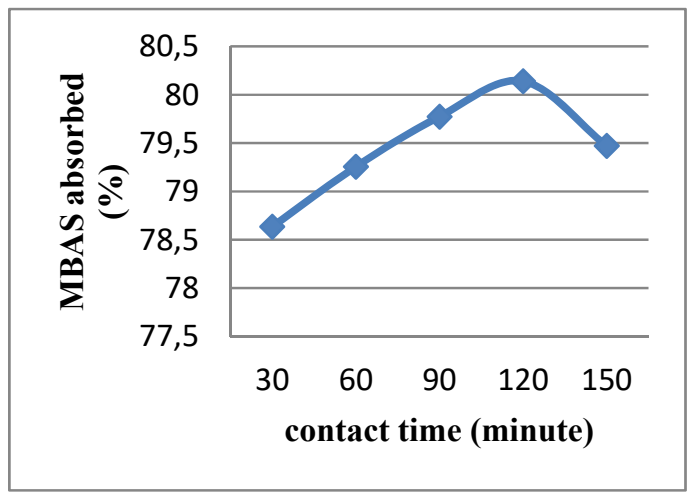

Figure 3. MBAS Absorption Chart on Time Variations

Figure 3 shows that at the contact time of 120 minutes, the percentage of MBAS concentration absorbed experienced the largest decrease of $80.14 \%$, while at the contact time of 30 minutes showed the lowest percentage of $78.63 \%$, but at contact time of more than 120 minutes the percentage of MBAS 
concentration absorbed has decreased. This is because the excessive contact time causes activated carbon to pass saturated and causes MBAS to be released from the pores of activated carbon (desorption occurs).

\section{Chemical Oxygen Demand (COD) According to SNI 6989.2-2009}

COD test principle are organic and inorganic compounds, especially organic in the test sample is oxidized by $\mathrm{Cr}_{2} \mathrm{O}_{7}^{2-}$ in the closed reflux produce $\mathrm{Cr}^{3+}$. The amount of oxidant needed is expressed in oxygen equivalents $\left(\mathrm{O}_{2} \mathrm{mg} / \mathrm{L}\right)$ measured by visible light spectrophotometry. $\mathrm{Cr}_{2} \mathrm{O}_{7}^{2-}$ strongly absorbs at a wavelength of $420 \mathrm{~nm}$ and $\mathrm{Cr}^{6+}$ strongly absorbs at a wavelength of $600 \mathrm{~nm}$. For COD values of $100 \mathrm{mg} /$ $\mathrm{L}$ up to $900 \mathrm{mg} / \mathrm{L}$ the increase in $\mathrm{Cr}^{6+}$ determined at a wavelength of $600 \mathrm{~nm}$. In the test sample with a higher COD value, dilution is performed before testing. For COD values, it is smaller or equal to 90 $\mathrm{mg} / \mathrm{L}$, the decrease in $\mathrm{Cr}_{2} \mathrm{O}_{7}^{2-}$ concentration is determined at a wavelength of $420 \mathrm{~nm}$. There action steps are as in ec $\Delta \mathrm{E}$

$\mathrm{C}_{\mathrm{x}} \mathrm{H}_{\mathrm{y}} \mathrm{O}_{\mathrm{z}}+\mathrm{K}_{2} \mathrm{Cr}_{2} \mathrm{O}_{7}{ }^{2-(\mathrm{l})}+11 \mathrm{H}^{+}(\mathrm{g}) \rightarrow \mathrm{CO}_{2(\mathrm{~g})}+2 \mathrm{Cr}^{3+}{ }_{(\mathrm{s})}+6 \mathrm{H}_{2} \mathrm{O}_{(\mathrm{g})}+\mathrm{K}^{+} . .(4)$

$\mathrm{Ag}_{2} \mathrm{SO}_{4}$

This reaction takes place \pm 2 hours, refluxed with a steam condenser apparatus, so that no volatile substances evaporate organic out. Then added silver sulfate which is useful to accelerate the reaction and mercury sulfate to eliminate chloride disturbances which are generally present in wastewater.

Table 3 shows the average COD concentration absorbed in the time variation. Figure 3 shows that the contact time from the 30 to the 120 minutes has increased graph and at 120 minutes the optimum time for adsorbent to absorb adsorbate and the concentration decreases. At 120 minutes contact time, the percentage of COD concentration absorbed is $79.34 \%$, while at 30 minutes contact time the percentage of COD concentration absorbed is $78.25 \%$. At contact time of more than 120 minutes the percentage of COD concentration absorbed has decreased. This shows that the contact time affects the decrease in COD concentration after addition of activated carbon.

The longer the contact time of the waste with activated carbon, the higher the average concentration of COD absorbed. Higher average concentration of COD was absorbed with increasing contact time allegedly because of active carbon which has been saturated to absorb organic matter in the waste involved desorbed after 120 minutes so add organic material to the sample resulting COD concentration rises.
Table 3. Average Absorbed COD Concentration in Contact Time Variations

\begin{tabular}{|c|c|c|c|c|c|}
\hline \multirow[t]{3}{*}{ No } & \multirow{3}{*}{$\begin{array}{c}\text { Contact } \\
\text { Time } \\
\text { (minutes) }\end{array}$} & \multicolumn{3}{|c|}{$\begin{array}{c}\text { COD concentration }(\mathrm{mg} \\
/ \mathrm{L})\end{array}$} & \multirow{3}{*}{$\begin{array}{c}\text { Percentage } \\
\text { of absorbed } \\
\text { COD } \\
\text { concentratio } \\
\text { n (\%) }\end{array}$} \\
\hline & & \multirow[t]{2}{*}{ Early } & \multicolumn{2}{|c|}{ Average } & \\
\hline & & & End & End & \\
\hline 1 & 30 & \multirow{5}{*}{$\begin{array}{c}1183 . \\
67\end{array}$} & 257.5 & 926,17 & 78.25 \\
\hline 2 & 60 & & 247 & 936.67 & 79.13 \\
\hline 3 & 90 & & 245.5 & 938,17 & 79.26 \\
\hline 4 & 120 & & 244.5 & 939,17 & 79.34 \\
\hline 5 & 150 & & 246 & 937.67 & 79.22 \\
\hline
\end{tabular}

Based on Table 3, a graph is made by connecting the time as the $\mathrm{X}$ axis to the amount of COD concentration absorbed $(\mathrm{mg} / \mathrm{L})$ as the $\mathrm{Y}$ axis. The results can be seen in Figure 4 .

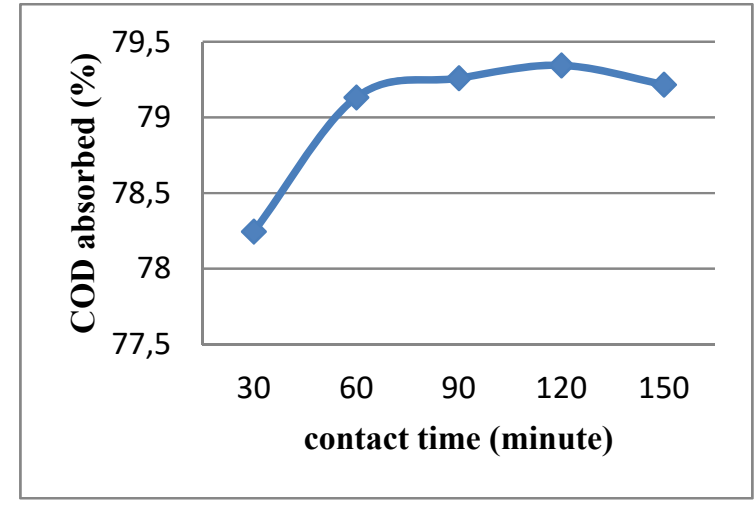

Figure 4. Graph of COD Absorption in Contact Time Variations

D. Biochemical Oxygen Demand (BOD) test according to SNI $6989.72: 2009$

BOD testing generally uses the Winkler-Alkali iodide azide method to determine dissolved oxygen levels. The principle is that oxygen in the sample will oxidize $\mathrm{MnSO}_{44}$ which is added to the solution in an alkaline state, so that $\mathrm{MnO}_{22}$ deposits occur. Addition of sulfuric acid and potassium iodide will be released iodine which is equivalent to dissolved oxygen. The released iodine was then analyzed by iodometric titration method with standard thiosulfate solution with starch indicator. The following is the reaction in the Winkler titration method:

$\mathrm{MnSO}_{4(\mathrm{aq})}+2 \mathrm{KOH}_{(\mathrm{aq})} \rightarrow \mathrm{Mn}(\mathrm{OH})_{2(\mathrm{aq})}+\mathrm{K}_{2} \mathrm{SO}_{4(\mathrm{aq})}$..(5)

$\mathrm{Mn}(\mathrm{OH})_{2(\mathrm{aq})}+\frac{1}{2} \mathrm{O}_{2} \rightarrow \mathrm{MnO}_{2(\mathrm{~s})}+\mathrm{H}_{2} \mathrm{O}_{(\mathrm{l})}$

$\mathrm{MnO}_{2(\mathrm{~s})}+2 \mathrm{KI}_{(\mathrm{a})}+2 \mathrm{H}_{2} \mathrm{O} \rightarrow \mathrm{Mn}(\mathrm{OH})_{2(\mathrm{aq})}+\mathrm{I}_{2}+2 \mathrm{KOH}$

(aq) $\quad . .(7)$

$\mathrm{I}_{2}+2 \mathrm{Na}_{2} \mathrm{~S}_{2} \mathrm{O}_{3} \rightarrow 2 \mathrm{NaI}_{(\text {aq })}+\mathrm{Na}_{2} \mathrm{~S}_{2} \mathrm{O}_{6}$ (aq) 
Table 4 shows the average concentration of BOD absorbed in the time variation. Figure 5 shows that the contact time from the 30 to the 120 minutes has increased graph and at 120 minutes the optimum time for adsorbent to absorb adsorbate and the concentration decreases. At 120 minutes contact time, the percentage of BOD concentration absorbed is $77.28 \%$, while at 30 minutes contact time the percentage of BOD concentration absorbed is $74.26 \%$. At contact time of more than 120 minutes, the percentage of BOD concentration absorbed has decreased. The decrease in BOD concentration coincides with the increase in contact time. This shows that the contact time affects the concentration of BOD waste after the addition of activated carbon.

Table 4. Average Absorbed BOD Concentration in Contact Time Variations

\begin{tabular}{|c|c|c|c|c|c|}
\hline \multirow[t]{3}{*}{ No } & \multirow{3}{*}{$\begin{array}{c}\text { Contact } \\
\text { Time } \\
\text { (minutes) }\end{array}$} & \multicolumn{3}{|c|}{$\begin{array}{l}\text { BOD concentration ( } \mathrm{mg} / \\
\text { L) }\end{array}$} & \multirow{3}{*}{$\begin{array}{c}\text { Percentage of } \\
\text { absorbed } \\
\text { BOD } \\
\text { concentration } \\
(\%)\end{array}$} \\
\hline & & \multirow[t]{2}{*}{ Early } & \multicolumn{2}{|c|}{ Average } & \\
\hline & & & End & Absorbed & \\
\hline 1 & 30 & \multirow{5}{*}{370.25} & 95.32 & 274.93 & 74.26 \\
\hline 2 & 60 & & 92,58 & 277.67 & 75.00 \\
\hline 3 & 90 & & 90.52 & 279.73 & 75,55 \\
\hline 4 & 120 & & 84.12 & 286.13 & 77.28 \\
\hline 5 & 150 & & 88.84 & 281.41 & 76.01 \\
\hline
\end{tabular}

Based on Table 4, a graph is made by connecting the time as the $\mathrm{X}$ axis to the amount of BOD concentration absorbed $(\mathrm{mg} / \mathrm{L})$ as the $\mathrm{Y}$ axis. The results of the graph can be seen in Figure 5 .

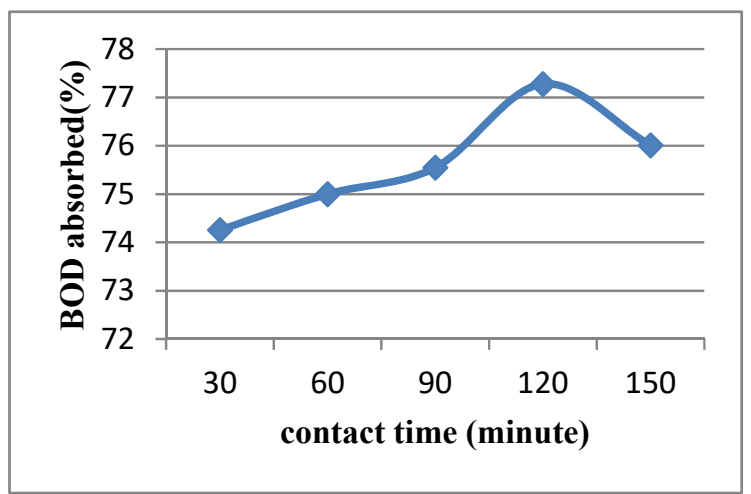

Figure 5. Graph of BOD Absorption in Time Variations

E. Total Suspended Solid Test (TSS) According to SNI 06-6989.3-2004
Testing of TSS concentration values aims to determine the total dissolved solids in wastewater. TSS comes from organic and inorganic compounds found in laundry wastes. Organic materials come from surfactants and additives, inorganic materials derived from detergent builders. At this stage laundry waste samples will be adsorbed with bagasse activated carbon which acts as an adsorbent. In table 5 shows the average concentration of TSS absorbed in the time variation.

Table 5. Average Concentration of TSS

Absorbed in Contact Time Variations

\begin{tabular}{|c|c|c|c|c|c|}
\hline \multirow[t]{3}{*}{ No } & \multirow{3}{*}{$\begin{array}{c}\text { Contact } \\
\text { Time } \\
\text { (minutes) }\end{array}$} & \multicolumn{3}{|c|}{ TSS concentration $(\mathrm{mg} / \mathrm{L})$} & \multirow{3}{*}{$\begin{array}{c}\text { Percentage of } \\
\text { TSS } \\
\text { concentration } \\
\text { absorbed (\%) }\end{array}$} \\
\hline & & \multirow[t]{2}{*}{ Early } & \multicolumn{2}{|c|}{ Average } & \\
\hline & & & End & Absorbed & \\
\hline 1 & 30 & \multirow{5}{*}{400} & 93.95 & 306.05 & 76.51 \\
\hline 2 & 60 & & 92.75 & 307.25 & 76.81 \\
\hline 3 & 90 & & 92.05 & 307.95 & 76.99 \\
\hline 4 & 120 & & 91.65 & 308.35 & 77.09 \\
\hline 5 & 150 & & 91.85 & 308.15 & 77.04 \\
\hline
\end{tabular}

Based on Table 5, a graph is made by connecting the time as the $\mathrm{X}$ axis to the amount of TSS concentration absorbed ( $\mathrm{mg} / \mathrm{L}$ ) as the $\mathrm{Y}$ axis. The graph results can be seen in Figure 6 .

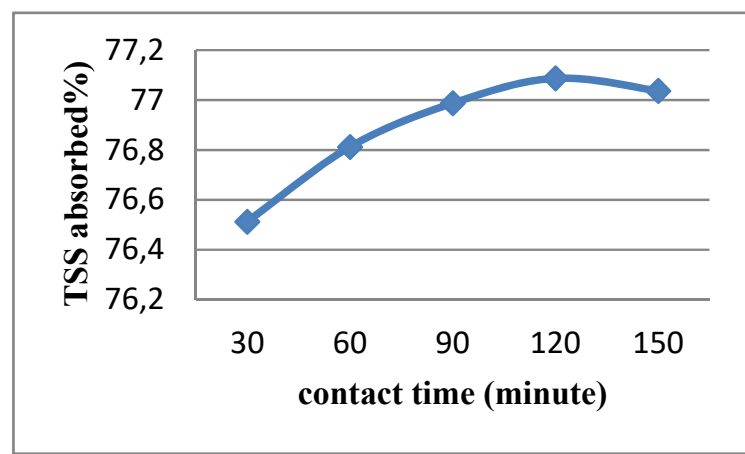

Figure 6. Graph of TSS Absorption in Time

Variations

Figure 6 shows that the contact time from the 30 to the 120 minutes has increased graph and at 120 minutes the optimum time for adsorbent to absorb adsorbate and the concentration decreases. At 120 minutes contact time, the percentage of TSS concentration absorbed is $77.09 \%$, while at 30 minutes contact time the percentage of TSS concentration absorbed is $76.51 \%$. At contact time of more than 120 minutes the percentage of TSS concentration absorbed has decreased. Activated carbon absorbs the impurity component by binding it to the porous structure of activated carbon. 


\section{F. pH Change Test According to SNI 06-6989.11- 2004}

The $\mathrm{pH}$ value is a parameter used to measure the acidity or concentration of $\mathrm{H}^{+}$values in water. $\mathrm{pH}$ values that are too acidic or too alkaline are not good for the waters because only extreme organisms can live in these waters. The $\mathrm{pH}$ value of laundry waste after the addition of activated carbon is presented in table 6 .

Table 6. $\mathrm{pH}$ data on various Contact time variations

\begin{tabular}{|c|c|c|c|}
\hline No & $\begin{array}{c}\text { Contact Time } \\
\text { (minutes) }\end{array}$ & $\begin{array}{c}\text { Initial } \\
\text { pH }\end{array}$ & Final pH \\
\hline 1 & 30 & \multirow{5}{*}{7.75} & 7.52 \\
\hline 2 & 60 & & 7.46 \\
\hline 3 & 90 & & 7.28 \\
\hline 4 & 120 & & 7.05 \\
\hline 5 & 150 & & 7.19 \\
\hline
\end{tabular}

Table 6 shows that the contact time from the 30 to the 120 minutes has decreased graph and at 120 minutes the optimum time for adsorbent has the lowest $\mathrm{pH}$. At the contact time of 120 minutes the lowest $\mathrm{pH}$ was 7.05 , while at 30 minutes contact time the highest $\mathrm{pH}$ was 7.52. At contact time of more than 120 minutes $\mathrm{pH}$ has increased. These results indicate that the contact time affects the $\mathrm{pH}$ value of laundry waste.

The $\mathrm{pH}$ value of laundry waste has decreased with longer contact time. Laundry waste contains alkaline detergents. Base absorption is carried out by activated carbon which contains groups of $\mathrm{H}^{+}$ions, which causes $\mathrm{pH}$ to fall.

The final results obtained from each parameter include MBAS which is $5.85 \mathrm{mg} / \mathrm{L}$, Phosphate of $4.00 \mathrm{mg} / \mathrm{L}, \mathrm{COD}$ of $244.5 \mathrm{mg} / \mathrm{L}$, BOD of $84.12 \mathrm{mg} /$ $\mathrm{L}$, TSS of $91.65 \mathrm{mg} / \mathrm{L}$, and $\mathrm{pH} 7.05$ and the final result has met the maximum limit specified by the East Java Governor Regulation No. 72 of 2013.

\section{CONCLUSION}

The results showed that the 120 minutes contact time between activated carbon from bagasse and laundry waste showed the best results seen from the percentage of phosphate concentration decrease of $82.99 \%$, MBAS of $80.14 \%$, COD of $79.34 \%$, BOD of $77,28 \%$, TSS amounted to $77.09 \%$ and showed a $\mathrm{pH}$ of 7.05 .

\section{BIBLIOGRAPHY}

[1] Stefhany, C.A., Sutisna, M. Pharmawati Phytoremidiation of Phosphates by Using Eichhornia crassipes in Small Industrial Liquid Waste. Clothing
Research (Laundry). Environmental Material, 2013, hlm: 1-11.

[2] Regulation of the Governor of East Java No. 72. Industrial Waste Water Quality Standards and Other Business Activities in East Java. Surabaya: Environmental Agency, 2013.

[3] Yuwono, Timoteus, Eduward Rolanda., Arief Widjaja \& Soeprijanto. Enzymatic Hydrolysate Fermentation of Sugarcane Bagasse into Hydrogen. Journal of Engineering Pomits, 2012, 1 (1): 1-5.

[4] Lavarack, B.P., Griffin, G.J., Rodman, D, The Acid Hydrolysis of Sugarcane Bagasse Hemicelluose to Produce Xylose, Arabinose, Glucose and Other Products. Biomass \& Bioenergy, 2002, 23: 367-380.

[5] Ganvir, V.N \& Syed Tanweer Ahmed. Synthesis of Activated Carbon From Toor Dall Husk (Cajanus Cajan Seed Husk) By Chemical Activation, International Journal of ChemTech Research, 2014, 6 (5): 2750-2754.

[6] Gumelar, Dalas, Effect of Activator and Contact Time on Performance of Active Charcoal Made from Water Hyacinth (Eichornia crossipes) on Decreasing Laundry Liquid Waste COD. Journal of Tropical Agricultural Engineering and Biosystems, 2015, Vol. 3 No.1, page: $15-23$.

[7] U.S. Dwi Saptati Nur Hayati, Silva Kurniawan, Nalita Widya Restu, Bambang Ismuyanto. Potential of Sugarcane Dregs as an Alternative to Making Activated Carbon Raw Materials. NATURAL B, 2016, Vol 3, No. 4: 311-317.

[8] Manocha, S.M. Porous Carbons. Sadhana, 2003, 28: 335-348

[9] Sawyer, C, N. Chemistry for Environmental Engineering and Science 5thedition. Singapore: Mc, Graw Hill Book Co., 2003

[10] Nailasa T, Wogo HE, Sometimes L. Utilization of kapok seed activated charcoal as an adsorbent of tofu liquid waste. Journal of Applied Chemistry. 2013, 1 (1): 40-49.

[11] Masduqi, Ali. Decreasing phosphate compounds in artificial wastewater by adsorption process using halloysite soil. Surabaya: FTSP ITS Environmental Engineering Department. Science and Technology Magazine, 2004, Vol. 15, No.1: 26-31.

[12] Washil, Ahmad. Determination of Anionic Surfactant Using Synergistic Extraction of Ion Mixture of Green Malasite and Blue Methylene Associations by Appearance Spectrophotometry. Essay. Malang: State Islamic University (UIN), 2009.

[13] Rangabhashiyam, S, et al. Sequestration of dye from textile industry wastewater using agricultural waste products as adsorbents. Journal of Environmental Chemical Engineering, 2013.

[14] Prasetyo Yhogi, Harun Nasrudin. Determination of $\mathrm{ZnCl}_{2}$ Concentration in the Process of Making Corn Activated Carbon and Reducing the Concentration of Alkyl Benzene Sulfonate (LAS) Linear Surfactants. Unesa Journal of Chemistry. 2013, Vol. 2: 231-235.

[15] Nunes, A.A., Franca, U.S., Oliveira, L, S. Activated Carbons from Waste Biomass: An Alternative Use for Biodiesel Production Solid Residues. Biosourse Technology. 2009, pp. 1786-1792.

[16] Khan, M.N., Zareen, U. Sand sorption process for the remval of sodium dodecyl sulfate (anionic surfactant) 
from water. J. Hazardous Mater, 2006, 133 (1-3): 269275.

[17] Gonzales-Garcia, GM, Gonzalez-Martin, ML, Gallardo-Moreno, AM, Gomez-Serrano, V., LabajosBroncano, L., Bruque, JM, Removal of an ionic surfactant from waste water by carbon adsorption ads blacks Sep. Sci. Technol, 2002, 37 (12), 2823-2837. 